\author{
Pawet Niedziótka \\ Instytut Bankowości \\ Szkoła Główna Handlowa w Warszawie
}

\title{
Zastosowanie kowenantów finansowych w bankowości korporacyjnej
}

\section{Streszczenie}

Kowenanty finansowe są coraz częściej stosowanymi narzędziami monitorowania kondycji ekonomiczno-finansowej klientów korporacyjnych. Ich wypełnienie jest potwierdzeniem realizacji projekcji finansowych będących podstawą udzielenia finansowania. Z kolei naruszenie pozwala na identyfikację w sposób obiektywny pogorszenia się kondycji ekonomiczno-finansowej dłużnika. W dobie coraz większej konkurencji w obszarze bankowości korporacyjnej należy spodziewać się intensyfikacji procesu implementowania kowenantów finansowych, gdyż służą one poprawie jakości monitoringu, ograniczają ryzyko operacyjne związane z udowodnieniem pogorszenia się bonitetu dłużnika jako podstawy wypowiedzenia umowy kredytowej, stanowią źródło dodatkowego dochodu dla banków oraz umożliwiają elastyczne dostosowanie ceny finansowania do poziomu ryzyka.

Słowa kluczowe: kowenanty finansowe, bankowość korporacyjna, ryzyko kredytowe, monitoring.

\section{Wprowadzenie}

Zgodnie z obowiązującym w Polsce prawem bankowym bank uzależnia przyznanie kredytu od zdolności kredytowej kredytobiorcy, przez którą rozumie się zdolność do spłaty kapitału wraz z odsetkami w terminach umownych [Wiatr 
2013, s. 163-167]. Jednocześnie kredytobiorca zobowiązany jest do przedłożenia bankowi wszystkich niezbędnych informacji do oceny zdolności kredytowej, zarówno na etapie udzielania finansowania, jak i w okresie kredytowania [Ustawa z dnia 29 sierpnia 1997 r., art. 70]. Bank okresowo monitoruje standing finansowy dłużników, aby móc:

- zweryfikować, czy klient wypełnia warunki określone w umowie kredytowej,

- ewentualnie niezwłocznie dostosować warunki finansowania do rosnącego ryzyka,

- skorygować poziom rezerw zawiązanych na daną wierzytelność (zawiązać, rozwiązać lub pozostawić na niezmienionym poziomie),

- dostosować warunki cenowe do poziomu ryzyka,

- wypowiedzieć umowę kredytową, jeśli zidentyfikowany poziom ryzyka z punktu widzenia banku okaże się nieakceptowalny.

Celem niniejszego artykułu jest prezentacja istoty, typologii, a przede wszystkim zastosowania kowenantów finansowych, które pełnią funkcję narzędzi monitorowania kondycji ekonomiczno-finansowej klientów korporacyjnych. Dają jednocześnie możliwość jednoznacznego i obiektywnego stwierdzenia, że nastąpiło pogorszenie lub poprawa standingu finansowego dłużnika lub poręczyciela. Należy spodziewać się, że ich zastosowanie w polskiej praktyce bankowej jako narzędzi monitoringu będzie coraz szersze, co wynika z upowszechniania się rachunkowości zgodnej ze standardami MSSF, które (18-19 MSSF 7) obligują kredytobiorcę do ujawnienia informacji o niespełnianiu przez jednostkę dodatkowych warunków (kowenantów) wynikających z umów zawartych z bankami [Zgodność sprawozdań... 2013, s. 20].

\section{Istota i taksonomia kowenantów finansowych}

Kowenanty finansowe należy rozumieć jako warunki, do których spełnienia w trakcie kredytowania zobligowany jest kredytobiorca, którego można zakwalifikować do segmentu bankowości korporacyjnej ${ }^{1}$. Coraz częściej są one wbudowywane nie tylko w bilateralne czy konsorcjalne umowy kredytowe, ale również kształtują ryzyko zaangażowania banku na rynku instrumentów pochodnych oraz na rynku papierów dłużnych. Badania przeprowadzone w 2003 r. na próbie 27 emisji amerykańskich obligacji stanowiących źródło finansowania inwestycji infrastrukturalnych dowodzi, że w 47,6\% przypadków zastosowano kowenanty opisujące zdolność do obsługi długu, zaś w 73,7\% przypadków występowały ograniczenia dotyczące dalszego zadłużania się [Dailami i Hauswald 2003, s. 11].

${ }^{1}$ Szerzej na temat istoty bankowości korporacyjnej oraz relationship banking zob. [Kaszuba 2011, s. 41-50]. 
Bank podejmuje działania restrykcyjne w stosunku do klienta, gdy nie dotrzyma on warunków udzielenia kredytu lub utraci zdolność kredytową. Do katalogu tych czynności zalicza się:

- obniżenie kwoty kredytu,

- wstrzymanie uruchomienia kredytu,

- żądanie zwiększenia pakietu zabezpieczeń kredytu,

- zwiększenie marży i/lub żądanie dodatkowej prowizji od kredytobiorcy,

- żądanie przedstawienia wiarygodnego (tj. m.in. zawierającego uwierzytelnione kontraktami przychody) planu naprawczego,

- wypowiedzenie umowy kredytowej².

Przypadkami niedotrzymania warunków umowy kredytowej są:

- wykazane przez bank rozbieżności między dokumentami, które kredytobiorca przekazał bankowi na etapie rozpatrywania wniosku o kredyt, i stanem faktycznym,

- wykorzystanie środków z kredytu niezgodnie z przeznaczeniem,

- nieustanowienie zabezpieczeń,

- znaczące obniżenie wartości zabezpieczeń,

- opóźnienia w obsłudze kredytu,

- istotne pogorszenie się kondycji ekonomiczno-finansowej klienta i/lub poręczyciela.

Większość wymienionych powyżej przypadków można obiektywnie wykazać, natomiast zasadniczym problemem jest udowodnienie, że faktycznie doszło do istotnego pogorszenia się kondycji ekonomiczno-finansowej dłużnika i/lub poręczyciela, stąd tak duże znaczenie kowenantów jako obiektywnych wyznaczników kondycji dłużnika.

Wyróżnić można następujące rodzaje kowenantów:

- wskaźnikowe - poziomy wskaźników finansowych, które nie powinny (lub powinny, w zależności od konstrukcji wskaźnika) być osiągnięte,

- limitujące poziom różnego rodzaju wydatków oraz zobowiązań finansowych dłużnika,

- obligujące kredytobiorcę do podjęcia określonych działań,

- zakazujące kredytobiorcy podejmowania określonych działań.

Niedotrzymanie kowenantu finansowego, jeśli nie zostanie uprzednio zaakceptowane przez kredytodawcę lub naprawione w wynikającym z umowy kredytowej terminie, oznacza przypadek naruszenia warunków umowy (event of default - EoD), formalnie uprawniający bank do wypowiedzenia umowy kredytowej i przedterminowego żądania spłaty kredytu. Jest to szczególnie

${ }^{2}$ Zdarza się to dość rzadko. Najczęściej dłużnik z odpowiednim wyprzedzeniem informuje wierzyciela o prawdopodobnym naruszeniu kowenantu, co sprawia, że w wyniku wzajemnych uzgodnień dochodzi do uaktualnienia warunków finansowania [Denis i Wang 2014, s. 35]. 
ważne z punktu widzenia dłużnika, gdyż coraz częściej już w standardowej dokumentacji kredytowej występuje, opisana w dalszej części artykułu, klauzula cross default. Zgodnie z nią przypadek naruszenia dowolnej umowy kredytowej oznacza naruszenie warunków pozostałych umów kredytowych (o ile oczywiście w tych umowach występuje klauzula cross default). Interesującym przypadkiem jest współfinansowanie określonego przedsięwzięcia za pomocą kredytów (dług nadrzędny) i pożyczek udziałowców (dług podporządkowany), gdy w poszczególnych umowach w innych sposób zdefiniowane są kowenanty. Skutkować to może ogłoszeniem przypadku naruszenia umów kredytowych przy braku przesłanek do identyfikacji takiego zdarzenia w umowie pożyczki podporządkowanej. Badania dowodzą, że np. w odniesieniu do transakcji LBO zazwyczaj w umowach pożyczek zawartych ze sponsorami (właścicielami) spółki celowej pojawia się więcej kowenantów niż w umowach SPV z bankami, lecz są to mniej restrykcyjne klauzule [Achleitner i Braun 2010, s. 35-36].

Należy wspomnieć, że oczywiście nie każda umowa kredytowa zawiera kowenanty finansowe. Duże, stabilne, o gruntowanej pozycji rynkowej przedsiębiorstwa, o które zabiega wielu potencjalnych kredytodawców, często nie akceptują dodatkowych nakładanych na nie zobowiązań, którymi są kowenanty finansowe. Zestaw kowenantów ujętych w umowie kredytowej nie jest w każdym przypadku taki sam - zależy on od aktualnej sytuacji ekonomiczno-finansowej kredytobiorcy, jego struktury właścicielskiej, dotychczas podjętych decyzji finansowych, planów i wielu innych czynników. Właściwie można stwierdzić, że jest on każdorazowo „szyty na miarę" (tailor made). Zwykle banki dysponują katalogiem standardowych kowenantów finansowych, ale w wyjątkowych przypadkach godzą się na niestandardowe definicje. Niestandardowość musi być jednak uzasadniona - jej przyczynami mogą być:

- specyfika sprawozdań finansowych klienta, wynikająca np. z dużego udziału zdarzeń jednorazowych, niestandardowych sposobów księgowania (np. amortyzacji znaków towarowych),

- to, że w innym banku klient zobligowany został do przestrzegania specyficznie zdefiniowanego kowenantu,

- sezonowość prowadzonej działalności.

Kowenanty finansowe, zwłaszcza wskaźnikowe, podlegają okresowej weryfikacji (zwykle kwartalnie). Odbywa się ona w sposób zautomatyzowany, jeśli kowenanty zdefiniowano w sposób wystandaryzowany i można wyliczyć wskaźniki na podstawie przekazanych przez dłużnika sprawozdań finansowych. Jeśli natomiast kowenanty odbiegają od standardu, wówczas bank żąda dostarczenia przez klienta tzw. certyfikatu zgodności, który powinien być podpisany zgodnie z reprezentacją spółki, a często również potwierdzony przez jej audytora. Niekiedy czynnikiem motywującym dłużnika do przygotowania certyfikatu zgodnie 
z zasadą najwyższej staranności i w terminie wynikającym z umowy kredytowej jest podwyższony poziom marży kredytowej (jeśli którykolwiek z ww. warunków nie zostanie wypełniony).

Oprócz częstotliwości weryfikacji kowenantów finansowych oraz ich precyzyjnego zdefiniowania, istotnymi kwestiami są również:

- przesądzenie, czy weryfikacja odbywa się na podstawie danych jednostkowych, czy też skonsolidowanych - decyzja w tej kwestii zależy od tego, czy finansowanie udzielone jest jednej spółce, czy też całej grupie kapitałowej. Zasadniczo nie ma uzasadnienia merytorycznego zastosowania kowenantów wskaźnikowych odnoszących się do danych skonsolidowanych, jeśli dłużnikiem jest pojedyncza spółka (nawet holdingowa), gdyż bank nie będzie uprawniony do reakcji (zgłoszenia przypadku naruszenia umowy kredytowej), gdy ewidentnemu pogorszeniu ulegnie kondycja dłużnika, a wskaźniki wykorzystane w konstrukcji kowenantu odnoszą się do wyników innych spółek (w szczególności tych, które nie są dłużnikami/poręczycielami);

- ustalenie, czy uwzględniane są dane kroczące, czy zannualizowane.

Kowenanty finansowe mają również pewne wady. Zaliczyć do nich można przede wszystkim ryzyko przedwczesnego podjęcia działań restrukturyzacyjno-windykacyjnych przez bank oraz przejęcie przez bank kontroli nad przedsiębiorstwem, co oznacza najczęściej przejście z zarządzania aktywnego na pasywne, negatywnie oddziałujące na innowacyjność firmy [Gu, Mao i Tian 2013, s. 1 i 28].

\section{Charakterystyka i zastosowanie kowenantów finansowych w bankowości korporacyjnej}

Kowenanty wskaźnikowe można z kolei podzielić na: 1) odnoszące się do zdolności do obsługi długu, 2) odwołujące się do poziomu zadłużenia lub minimalnego poziomu kapitałów własnych.

Zdolność do obsługi długu weryfikowana jest za pomocą:

- wskaźnika obsługi długu (debt service coverage ratio), definiowanego jako stosunek skorygowanego EBITDA (earnings before interest, taxes, depreciation and amortisation) w danym okresie do planowanej na ten okres obsługi długu,

- wskaźnika pokrycia odsetek (interest coverage ratio - ICR), określanego jako stosunek EBIT (earning before interest and taxes) w danym okresie do łącznej kwoty odsetek do zapłaty w tym czasie.

EBITDA identyfikuje się z wynikiem na działalności operacyjnej powiększonym o amortyzację lub powiększonym o amortyzację wynikiem na działalności operacyjnej skorygowanym o wszelkie pozycje nadzwyczajne, jednorazowe, niepowtarzalne, koszty i przychody niewynikające z działalności podstawowej 
kredytobiorcy (np. odpisy z tytułu utraty wartości środków trwałych lub wartości niematerialnych i prawnych, zawiązanie rezerw na należności lub ich rozwiązanie itp.). Należy jednocześnie zauważyć, że EBITDA nie odzwierciedla dokładnie salda środków pieniężnych wygenerowanych z działalności operacyjnej, który to poziom gotówki stanowi źródło obsługi długu i wydatków inwestycyjnych (oczywiście zakładając, że nie nastąpią dezinwestycje i spółka nie pozyska dodatkowego finansowania). Aby realnie ocenić zdolność do obsługi długu, należy zatem skorygować EBITDA o zmianę poziomu kapitału obrotowego. Z kolei w przypadku wskaźnika ICR zastosować można dwa alternatywne warianty: 1) EBIT za dany kwartał i odsetki za dany kwartał, 2) EBIT za ostatnie 4 kwartały i odsetki za ostatnie 4 kwartały.

Wśród wskaźników opisujących poziom zadłużenia wymienić można:

- dług netto/EBITDA (net debt/EBITDA, ND/EBITDA),

- loan life coverage ratio (LLCR) oraz project life coverage ratio (PLCR),

- zadłużenie oprocentowane/kapitał własny (debt/equity),

- wskaźnik zadłużenia (indebtedness ratio).

Wskaźnik dług netto/EBITDA ma za zadanie wskazać okres, w którym spółka będzie w stanie spłacić swoje zobowiązania generujące koszty finansowe ze środków z działalności podstawowej. Dług netto stanowi sumę wszystkich krótkoterminowych i długoterminowych kredytów oraz obligacji i innych instrumentów dłużnych pomniejszoną o saldo środków pieniężnych. Niekiedy tę listę zobowiązań poszerza się o zobowiązania leasingowe, wierzytelności sprzedane z prawem regresu oraz kwoty pozyskane na podstawie innej transakcji mającej skutki pożyczki, gwarancji lub poręczenia, wyłączając jednak negatywną z punktu widzenia kredytobiorcy wycenę instrumentów pochodnych oraz pożyczki podporządkowane (tzn. takie, które nie są obsługiwane w okresie kredytowania). Poziom EBITDA zdefiniowany został we wcześniejszej części artykułu.

Wskaźnikami, które wykorzystywane są w przypadku długoterminowych kredytów inwestycyjnych, są również LLCR i PLCR. Pełnią one funkcję zbliżoną do wskaźnika dług netto/EBITDA, uwzględniając jednak wartość pieniądza w czasie. LLCR jest stosunkiem wartości bieżącej EBITDA (tzw. NPV of EBITDA) do salda niepodporządkowanego zasłużenia, przy czym kalkulacja wartości bieżącej EBITDA ma miejsce w okresie kredytowania. PLCR tym różni się od LLCR, że estymacja wartości bieżącej EBITDA obejmuje nie tylko okres kredytowania, ale cały okres trwania projektu. Precyzyjne zdefiniowanie kowenantu opartego na wskaźnikach LLCR lub PLCR wymaga przesądzenia, czy wartość bieżąca EBITDA korygowana jest (in plus) o saldo środków zgromadzonych na różnego rodzaju rachunkach rezerwowych (np. na rachunku rezerwy obsługi długu, czyli debt service reserve account - DSRA). Uwzględnienie tych kwot skutkuje wyższymi (lepszymi) wartościami LLCR oraz PLCR. Zwykle 
PLCR przyjmuje wyższe wartości niż LLCR. Nie dotyczy to jednak projektów górniczych, w których przypadku na końcu inwestycji ponoszone są duże nakłady rekultywacyjne.

Wskaźnik zadłużenie oprocentowane/kapitał własny informuje o poziomie lewarowania kredytobiorcy. Podmiot, na który nałożono ten kowenant, aby nie doszło do przypadku naruszenia warunków umowy kredytowej, ma zasadniczo do wyboru redukcję zadłużenia przez jego spłatę lub pozostawianie przynajmniej części wypracowanego zysku w spółce. W skrajnym przypadku niezbędne jest dokapitalizowanie i przekazanie części środków na spłatę długu. Podwyższony poziom lewarowania spółki ma sens wtedy, gdy jej rentowność przewyższa koszt kapitału obcego - wówczas tworzy się dodatkowa marża dla właścicieli, zwiększająca ich zwrot z zaangażowanego kapitału. Optymalny poziom wskaźnika zadłużenie kredytowe/kapitał własny zależy od branży. W sektorach kapitałochłonnych akceptowalne są relatywnie wyższe wartości niż w branżach wymagających niższego kapitału.

Wskaźnik zadłużenia opisuje udział wszystkich zobowiązań kredytobiorcy w jego sumie bilansowej. Trudno określić maksymalny poziom tego wskaźnika, ale w przypadku zdecydowanej większości banków poziom wyższy od 90\% uznaje się za krytyczny. Jego przekroczenie oznacza bardzo wysoki poziom lewarowania działalności spółki i szczególnie w przypadku podmiotów regularnie wypłacających dywidendę może przekładać się na obniżoną motywację właścicieli w zakresie wsparcia spółki w okresie dekoniunktury i ujawnić swego rodzaju pokusę nadużycia, kierującą decyzjami właścicieli (przeniesienie odpowiedzialności na wierzycieli). Ograniczona baza kapitałowa spółki w porównaniu z jej skalą wyrażoną przychodami ze sprzedaży oraz sumą bilansową kreuje ryzyko dekapitalizacji, jeśli w danym okresie działalność odznaczać się będzie deficytowością. Przez optymalny poziom tego wskaźnika rozumie się taki, który zapewni właścicielom spółki satysfakcjonującą stopę zwrotu z zaangażowanego kapitału (ROE) i jednocześnie determinować będzie poziom długu, który nawet w okresie pogorszenia koniunktury rynkowej będzie mógł być obsługiwany terminowo. Wskaźnik zadłużenia należy zatem wiązać z wcześniej opisanymi wskaźnikami obsługi długu, co oznacza, że przy relatywnie wysokiej rentowności i wysokim poziomie EBITDA bank może zaakceptować spółkę o relatywnie wysokim poziomie zadłużenia w stosunku do sumy bilansowej. W kontekście analizy wskaźnika zadłużenia w roli potencjalnego kowenantu finansowego nie bez znaczenia jest również struktura długu, którą należy rozpatrywać dwojako: po pierwsze jako relację między nadrzędnym długiem oprocentowanym i pozostałym zadłużeniem (kredyt kupiecki oraz pożyczki podporządkowane), po drugie zaś pod kątem struktury czasowej wymagalności zobowiązań. Przy danej zdolności do obsługi długu i określonej wartości wskaźnika zadłużenia bank przychylniej patrzy na przedsiębiorstwa charakteryzujące się relatywnie 
wyższym udziałem długu podporządkowanego i kredytu kupieckiego. Wynika to ze stosunkowo wyższej zdolności takiego przedsiębiorstwa do obsługi długu w porównaniu z podmiotem, który w większym stopniu korzysta z kredytu bankowego i papierów dłużnych. Należy bowiem wspomnieć, że najczęściej odsetki od długu podporządkowanego podlegają kapitalizacji, czego efektem są jednak wyższe koszty finansowe (choć niekasowe) podwyższające prawdopodobieństwo poniesienia przez spółkę ujemnego wyniku netto. Nieco mniej skutecznym rozwiązaniem problemu nadmiernego zadłużenia i nieprawidłowej struktury finansowania przedsiębiorstw jest kowenant ograniczający poziom wypłaconej dywidendy lub obligujący do utrzymywania określonego poziomu kapitału własnego. Stosuje się w tym zakresie następujące warianty:

- zakaz wypłaty dywidendy w całym okresie kredytowania,

- zgodę na wypłatę do określonego procentu zysku netto zakończonego roku obrachunkowego,

- zgodę na wypłatę dywidendy, jeśli przed wypłatą i po wypłacie nie zostaną złamane kowenanty finansowe i jeśli np. wskaźnik dług netto/EBITDA spadnie poniżej poziomu 2,5 ,

- zobowiązanie do utrzymywania kapitału własnego na poziomie nie niższym od określonej kwoty.

Niedoskonałość kowenantów ograniczających poziom wypłacanej dywidendy wynika m.in. z tego, że intencja utrzymania akceptowalnej struktury finansowania wymaga zastosowania dodatkowego kowenantu, jak również zdefiniowania maksymalnego poziomu zadłużenia. W przeciwnym razie poza kontrolą pozostaje poziom zadłużenia. Należy jednocześnie zwrócić uwagę, aby wypłata dywidendy ograniczała się do zysku ostatniego roku zakończonego obrachunkowego, a nie opierała się na wcześniej wypracowanych zyskach (wówczas miałaby miejsce dwojakiego rodzaju dekapitalizacja: przez redukcję wcześniej zgromadzonego kapitału oraz przez stratę roku bieżącego). Banki nie godzą się najczęściej również na zaliczkową wypłatę dywidendy. Wypełnienie kowenantów służących ograniczeniu ryzyka nadmiernego lewarowania spółki skutkuje często wyborem przez właścicieli finansowanego podmiotu projektów odznaczających się wyższą oczekiwaną rentownością, aby dzięki temu zmaksymalizować poziom ROE [Śmieja i Pauka 2013, s. 556-557].

Do grupy kowenantów kształtujących limity wydatków oraz zobowiązań finansowych dłużnika zaliczyć należy:

- maksymalny CAPEX, w tym poziom środków, które mogą być wydatkowane na akwizycje spółek,

- maksymalną wartość rozporządzeń majątkowych, na które nie jest potrzebna zgoda banku,

- maksymalny poziom udzielonych pożyczek, nabytych papierów dłużnych itp. 
Zdolność do obsługi zadłużenia jest funkcją nie tylko poziomu przepływów operacyjnych przedsiębiorstwa, ale także możliwości przeznaczenia tych środków na inne cele poza spłatą odsetek, prowizji i rat kapitałowych. Z tych powodów w umowach kredytowych wprowadza się kowenanty ograniczające poziom wydatków inwestycyjnych (CAPEX). Nie chodzi tu oczywiście o powstrzymanie rozwoju kredytowanej spółki, bo godziłoby to również w interesy kredytującego ją banku, ale raczej o to, aby zachować racjonalną relację między inwestycjami i tempem delewarowania, jak również nie dopuścić do sytuacji, gdy kredytobiorca tłumaczy brak zdolności do obsługi długu realizacją kapitałochłonnych przedsięwzięć, co więcej niekiedy takich, w przypadku których nie posiada domknięcia finansowego, lub projektów, których realizacja skutkuje okresową redukcją mocy produkcyjnych. Zdolność do obsługi długu kredytobiorcy uległaby również erozji, gdyby wolne środki pieniężne zostały przeznaczone na udzielanie pożyczek, zakup papierów dłużnych lub akcji - z tego względu banki nakładają na dłużników ograniczenia w tym zakresie (lub zakaz wydatkowania środków na wskazane powyżej formy inwestycji).

Kowenantami obligującymi do podejmowania określonych działań lub ich zaniechania są z kolei:

- zobowiązanie w zakresie dostarczania sprawozdań finansowych oraz certyfikatów zgodności,

- zobowiązanie do równego traktowania wierzycieli (tzw. klauzula pari passu),

- zobowiązanie do przeprowadzania określonego poziomu obrotów przez rachunki klienta w banku, co stanowić może źródło dodatkowego dochodu nieobciążonego ryzykiem kredytowym [Hansen 2010],

- negative pledge, czyli zobowiązanie do nieobciążania majątku oraz do niepodejmowania innych przesunięć majątkowych, które mogłyby utrudniać zaspokojenie roszczeń wierzyciela bez jego zgody.

\section{Wnioski końcowe}

Kowenanty finansowe są coraz częściej stosowanymi narzędziami monitorowania kondycji ekonomiczno-finansowej klientów korporacyjnych korzystających z kredytów bankowych. Ich wypełnienie jest swego rodzaju potwierdzeniem realizacji projekcji finansowych będących podstawą udzielenia finansowania. Z kolei naruszenie pozwala na identyfikację w sposób obiektywny stanu pogorszenia się kondycji ekonomiczno-finansowej dłużnika. Kowenanty finansowe nie są wyłącznie domeną rynku kredytowego. Coraz częściej wprowadzane są do dokumentacji związane $\mathrm{z}$ transakcjami terminowymi zawieranymi zgodnie ze standardem ISDA [Niedziółka 2009, s. 22]. Służą również kontroli ryzyka 
z punktu widzenia inwestorów na rynku obligacji korporacyjnych. O użyteczności kowenantów świadczy zapoczątkowana w 2010 r. inicjatywa inwestorów reprezentujących brytyjskie i niemieckie sektory ubezpieczeń i funduszy inwestycyjnych (tzw. Bond Covenant Group), aby wdrożyć standardowy zestaw kowenantów dla euroobligacji jako pewnego rodzaju minimum informacyjne zapewniające transparentność emitentów [Hornuf, Reps i Schäferling 2014, s. 18].

Kowenant to również ważne narzędzie w systemie wczesnego ostrzegania i instrument umożliwiający podjęcie relatywnie szybko działań restrukturyzacyjnych oraz dostosowanie ceny finansowania do faktycznego poziomu ryzyka (przez tzw. waiver fee, którą w przypadku wyrażenia zgody przez banki na odstąpienie od działań restrykcyjnych w sytuacji powstania przypadku naruszenia, zobligowany jest uiścić dłużnik lub przez podniesienie marży) ${ }^{3}$. Szczególnie duże znaczenie przypisywane jest wskaźnikom występującym w roli kowenantów bardzo często wysokość marży kredytowej jest funkcją wartości wskaźników na koniec poszczególnych okresów.

Reasumując, w dobie coraz większej konkurencji w obszarze bankowości korporacyjnej należy spodziewać intensyfikacji procesu implementowania kowenantów finansowych w umowach kredytowych, gdyż służą one poprawie jakości monitoringu, ograniczają ryzyko operacyjne związane z udowodnieniem pogorszenia się bonitetu dłużnika jako podstawy wypowiedzenia umowy kredytowej, stanowią źródło dodatkowego dochodu dla banków oraz umożliwiają elastyczne dostosowanie ceny finansowania do poziomu ryzyka.

\section{Literatura}

Achleitner A.K., Braun R. [2010], Structure and Determinants of Financial Covenants in Leveraged Buyout - Evidence from an Economy with Strong Creditor Rights, red. B. Hinterramskogler i F. Tappeiner, The Open Access Publication Server of the ZBW Leibniz Information Centre for Economics, CEFS Working Paper Series, nr 2009-15. Dailami M., Hauswald R. [2003], The Emerging Project Bond Market: Covenant Provisions and Credit Spreads, World Bank Policy Research Working Paper nr 3095, Washington.

Denis D.J., Wang J. [2014], Debt Covenant Renegotiations and Creditor Control Rights, „Journal of Financial Economics”, vol. 113, nr 3.

Gu Y., Mao C.X., Tian X. [2013], Creditor Interventions and Firm Innovation: Evidence from Debt Covenant Violations, Working Papers Series Available at SSRN: http://ssrn. com/abstract=2329007; http://dx.doi.org/10.2139/ssrn.2329007.

Hansen G. [2010], Wzmożone zainteresowanie kowenantami, http://inwestycje.pl/banki/ banki__wzmozone_zainteresowanie_kowenantami;86956;0.html (dostęp: 11.03.2014).

${ }^{3}$ Z drugiej strony zastosowanie tzw. margin grid (siatki marż) umożliwia dłużnikowi obniże-

nie kosztu finansowania w przypadku poprawy jego kondycji finansowej [Jiang 2012, s. 2]. 
Hornuf L., Reps M., Schäferling S. [2014], Covenants in European Investment-Grade Corporate Bonds, Working Papers Series Available, http://ssrn.com/abstract=2393291; http://dx.doi.org/10.2139/ssrn.2393291.

Jiang J. [2012], How Does Managerial Entrenchment Affect Loan Covenant Violation?, Working Papers Series Available, http://ssrn.com/abstract=2386517; http://dx.doi. org/10.2139/ssrn.2386517.

Kaszuba S. [2011], Współczesny bank korporacyjny jako partner przedsiębiorczości [w:] Wspótczesna bankowość korporacyjna, red. A. Szelągowska, CeDeWu, Warszawa.

Niedziółka P. [2009], Problem opcji walutowych w Polsce w latach 2008-2009-analiza z perspektywy sektora bankowego, Studia i Prace Kolegium Zarządzania i Finansów, nr 95, SGH, Warszawa.

Śmieja N., Pauka M. [2013], Analiza kowenantów w obligacjach korporacyjnych emitowanych przez niebankowe spółki z branży finansowej, Annales Universitatis Mariae Curie-Skłodowska, vol. XLVII, nr 3, Lublin.

Ustawa z dnia 29 sierpnia 1997 r. Prawo bankowe, Dz.U. nr 140 poz. 939.

Wiatr M.S. [2013], Ryzyko w działalności bankowej [w:] Bankowość, red. M. Zaleska, Wydawnictwo C.H. Beck, Warszawa.

Zgodność sprawozdań finansowych emitentów papierów wartościowych z MSSF. Analiza przeprowadzona w 2012 r. [2013], Urząd Komisji Nadzoru Finansowego, Warszawa.

\section{Possible Applications of Financial Covenants in Corporate Banking}

Financial covenants are tools used to monitor the economic and financial performance of corporate debtors. Their fulfilment is a kind of confirmation of the implementation of financial projections analysed at the processing stage of credit applications. In turn, their violation offers objective proof that an obligor's financial standing has deteriorated. It is expected that the increasing competition in corporate banking will see extensive implementation of financial covenants, as they improve the quality of monitoring, reduce the operational risk involved in proving that a debtor's credit rating has deteriorated (thus providing grounds for terminating credit agreements), are a source of additional income for banks and allow flexible adjustment of the price according to the risk level.

Keywords: financial covenants, corporate banking, credit risk, monitoring. 